\title{
Adherence of Mycoplasma gallisepticum to Glass
}

\author{
By I. KAHANE, O. GAT, M. BANAI, W. BREDT* AND S. RAZIN \\ Biomembrane Research Laboratory, Department of Clinical Microbiology, \\ The Hebrew University-Hadassah Medical School, Jerusalem, Israel \\ *Institute for General Hygiene and Bacteriology, Center for Hygiene, \\ Albert-Ludwigs Universität, D-7800 Freiburg, West Germany
}

(Received 13 July 1978; revised 18 September 1978)

\begin{abstract}
Attachment of washed Mycoplasma gallisepticum cells to glass was quantified with organisms in which membrane lipids were labelled with ${ }^{3} \mathrm{H}$. Siliconization of the test tubes decreased attachment, while centrifugation increased it. Attachment increased with temperature, decreased with increasing $\mathrm{pH}$ and ionic strength of the attachment mixture, but was unaffected by $\mathrm{Ca}^{2+}, \mathrm{Mg}^{2+}$ and EDTA. This suggests that ionic bonds, but not salt bridges, participate in the attachment process. Glycophorin, the major receptor responsible for $M$. gallisepticum attachment to erythrocytes, partially inhibited the attachment of the organisms to glass. However, bovine serum albumin also decreased attachment. Extensive pretreatment of the organisms with trypsin decreased their ability to attach to glass by about 35 to $40 \%$. Trypsin and pronase failed to detach the organisms already bound to glass, suggesting that external mycoplasma cell components, other than membrane proteins, also participate in attachment of the organisms to glass.
\end{abstract}

\section{INTRODUCTION}

The adherence of mycoplasmas to host cell surfaces appears to play an important role in their pathogenicity. Current studies in several laboratories are aimed at determining the chemical nature of the receptor sites on the host cell and the binding sites on the parasite (for review, see Razin, 1978). There is strong evidence that the sialic acid moieties of the host membrane glycoproteins and/or glycolipids act as specific receptor sites for the respiratory pathogens Mycoplasma pneumoniae and Mycoplasma gallisepticum (Gesner \& Thomas, 1966; Sobeslavsky et al., 1968; Manchee \& Taylor-Robinson, 1969; Gorski \& Bredt, 1977; Banai et al., 1978; Razin, 1978). The nature of the binding sites on the mycoplasma surface is less clear, although recently a membrane protein has been implicated as the binding site of $M$. pneumoniae responsible for its attachment to tracheal epithelial cells (Hu et al., 1977).

The fact that many of the mycoplasmas capable of adhering to eukaryotic cells also tend to adhere strongly to inert surfaces, such as glass and plastic, has been known for some time (Somerson et al., 1967; Taylor-Robinson \& Manchee, 1967). The tendency of $M$. pneumoniae and $M$. gallisepticum to attach to glass and plastic during growth has been used to simplify the procedure of cell harvest and to facilitate the preparation of antigens relatively free from serum proteins precipitated from the growth medium (Somerson et al., 1967; Warren et al., 1968; Purcell et al., 1971). Little has been done to elucidate the mechanism of mycoplasma attachment to inert surfaces. In the few studies carried out, the methods used were not sensitive enough to determine the quantity of mycoplasmas attached to the surface. These methods included observations with the light microscope, viable counts and determination 
of protein and of antigenic potency (Somerson et al., 1967; Taylor-Robinson \& Manchee, 1967; Purcell et al., 1971; Gorski \& Bredt, 1977). The shortcomings of these techniques are illustrated by the finding of Taylor-Robinson \& Manchee (1967) that viable counts of $M$. gallisepticum attached to plastic did not correspond to protein determinations. In our recent study on the adherence of $M$. gallisepticum to human erythrocytes (Banai et al., 1978), we made use of mycoplasmas with labelled membrane lipids to facilitate their quantification. We have now utilized similarly labelled mycoplasmas to investigate the factors affecting their attachment to glass, and so compare this phenomenon with adherence of the same mycoplasmas to eukaryotic cells.

\section{METHODS}

Organisms and growth conditions. Mycoplasma gallisepticum A5969 was grown in modified Edward medium (Razin \& Rottem, 1976) containing $4 \%(\mathrm{v} / \mathrm{v})$ horse serum. To label membrane lipids, the medium was supplemented with $\left[9,10-{ }^{3} \mathrm{H}\right]$ palmitic acid $\left(100 \mu \mathrm{Ci} 1^{-1}\right.$, sp. act. $500 \mathrm{mCi} \mathrm{mmol}^{-1}$; The Radiochemical Centre, Amersham). The organisms were harvested after 18 to $20 \mathrm{~h}$ incubation at $37^{\circ} \mathrm{C}\left(A_{640} 0.18\right.$ to $\left.0 \cdot 25\right)$. They were washed once with $0.1 \mathrm{M}-\mathrm{NaCl}$ containing $1 \mathrm{mM}^{-\mathrm{CaCl}_{2}}$ and $0.05 \mathrm{M}$-Tris $\mathrm{pH} 7.2$ (buffer A), resuspended in the same buffer solution to about $1 \mathrm{mg}$ protein $\mathrm{ml}^{-1}$ and used the same day.

Assessment of mycoplasma attachment. The attachment mixture consisted of $0 \cdot 1 \mathrm{ml} \mathrm{M}$. gallisepticum suspension (containing about $15 \mu \mathrm{g}$ protein, equivalent to about $1 \times 10^{8}$ to $2 \times 10^{8}$ viable organisms) and $0.1 \mathrm{ml}$ buffer $A$ in a serological borosilicate glass test tube $(12 \mathrm{~mm}$ diam. $\times 100 \mathrm{~mm})$. After $30 \mathrm{~min}$ incubation at $37^{\circ} \mathrm{C}$ with shaking ( 90 strokes min ${ }^{-1}$, amplitude $3.5 \mathrm{~cm}$ ), $0.5 \mathrm{ml}$ cold buffer A was added, the test tube was shaken gently and then its contents were removed by suction. Residual unattached or loosely attached mycoplasmas were removed by two subsequent additions of cold buffer A ( $2 \mathrm{ml}$ each) to the test tube and removal by suction. To determine the amount of mycoplasmas still attached to the glass surface, $0.5 \mathrm{ml}$ buffer $\mathrm{A}$ and $0.1 \mathrm{ml} 1 \%$ (w/v) sodium dodecyl sulphate were added to each test tube, mixed well using a Vortex mixer and left overnight at room temperature. Duplicate samples $(0.2 \mathrm{ml}$ each) were then transferred to scintillation vials for counting, using Triton X-100/toluene scintillation fluid (Kahane \& Razin, 1977).The radioactivity values were converted to protein according to the specific radioactivity of the batch of cells [c.p.m. (mg protein) ${ }^{-1}$ ] used in the experiment.

Treatment with trypsin. Samples of $M$. gallisepticum suspension $(3.0 \mathrm{ml}, 2.4 \mathrm{mg}$ protein) in buffer A, ad-

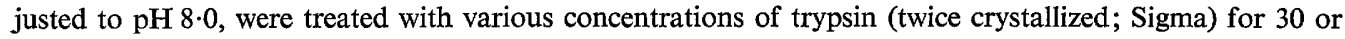
$60 \mathrm{~min}$ at $37^{\circ} \mathrm{C}$. A test tube containing the coloured substrate Azocoll (Calbiochem) was included as a control for enzymic activity. Digestion was stopped by adding the trypsin inhibitor $N$ - $\alpha$-p-tosyl-L-lysine chloromethyl ketone. $\mathrm{HCl}$ (Sigma) to a concentration about twice that of the enzyme. After 3 min incubation with shaking, the organisms were sedimented by centrifugation in the cold at $21000 \mathrm{~g}$ for $20 \mathrm{~min}$, washed once with buffer $\mathrm{A}$ and resuspended in the same buffer to give $150 \mu \mathrm{g}$ protein $\mathrm{ml}^{-1}$.

To test the effect of trypsin on organisms attaching during growth, $M$. gallisepticum was grown for $24 \mathrm{~h}$ in $2.0 \mathrm{ml}\left[{ }^{3} \mathrm{H}\right]$ palmitate medium in serological test tubes similar to those used for testing attachment. The culture fluids were then collected by suction and the test tubes were washed three times with $2 \cdot 0 \mathrm{ml}$ buffer $\mathrm{A}$ as described above. Trypsin solution $\left(2.0 \mathrm{ml}, 25 \mu \mathrm{g} \mathrm{ml}^{-1}\right.$ in buffer $\left.\mathrm{A}, \mathrm{pH} 8.0\right)$ was added to each of the washed test tubes. After $30 \mathrm{~min}$ incubation at $37^{\circ} \mathrm{C}$ the contents of the test tubes were removed by suction. The test tubes were then washed twice with buffer $\mathbf{A}$ and the radioactivity remaining attached to the glass was determined as described above.

Analytical procedures. Protein was determined by the method of Lowry et al. (1951). Glycophorin, the major sialoglycoprotein of erythrocyte membranes, was isolated and purified according to Marchesi \& Andrews (1971).

\section{RESULTS AND DISCUSSION}

The use of mycoplasmas with labelled membrane lipids provided a sensitive means of quantifying their attachment to glass. The three washings employed in our standard procedure were sufficient to remove all the unattached or loosely attached mycoplasmas since further washing failed to remove any additional radioactivity from the test tubes. Attachment of the mycoplasmas to the glass increased linearly with the amount of mycoplasmas in the test tube up to $50 \mu \mathrm{g}$ protein (Fig. 1); above this concentration there was some deviation from linearity. In order to remain within the linear range, 15 to $30 \mu \mathrm{g}$ protein per 


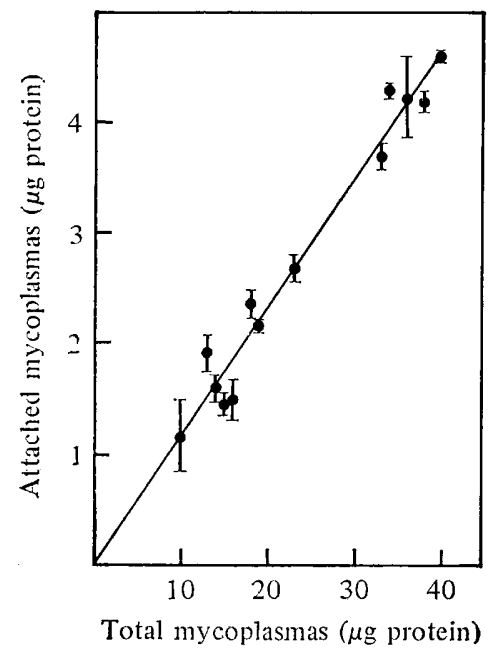

Fig. 1. Attachment of $M$. gallisepticum to glass as a function of the amount of mycoplasmas in the test tube. Data were collected from about 20 different experiments.

tube was used in all subsequent experiments. About $10 \%$ of the organisms became firmly attached to the glass under our standard conditions (Fig. 1), a result similar to that obtained by Banai et al. (1978) for the attachment of $M$. gallisepticum to human erythrocytes. To find out whether the remaining $90 \%$ of the population differed in their attachment capacity, the supernatant fluids collected after the first attachment test were transferred to new test tubes and tested for attachment under the standard conditions. The percentage of mycoplasmas attached to glass in the second test did not differ significantly from that in the first attachment test. In the experiments of Banai et al. (1978), the population remaining unattached after exposure to erythrocytes exhibited less than one-tenth of the attachment capacity of the original population as determined by a second attachment test. The different results suggest that the percentage of the $M$. gallisepticum population capable of adhering to glass is much higher than that capable of adhering to erythrocytes.

The relatively low percentage of $M$. gallisepticum attached to glass under our experimental conditions may be due to limited opportunities for contact between the organisms and the glass. Increasing contact by centrifugation did, in fact, increase the percentage of attached mycoplasmas from $10 \%$ to over $50 \%$ of the total population (Fig. 2). In contrast, siliconization of the glass tubes decreased attachment (Fig. 2).

The attachment curves shown in Fig. 3 appear to follow first-order kinetics and to be influenced by temperature, suggesting that attachment to glass is a process where the number of particles adsorbed at any given time is dependent on the frequency of their collision with the adsorptive surface. Attachment decreased on increasing the $\mathrm{pH}$ of the attachment mixture (Fig. 4) or on increasing its ionic strength (Fig. 5). Nevertheless, once attachment had taken place, the organisms could not be detached from the glass by washing with $1 \mathrm{M}-\mathrm{NaCl}$. The addition of $\mathrm{Ca}^{2+}$ or $\mathrm{Mg}^{2+}$ to the attachment mixture at concentrations ranging from $10^{-5}$ to $10^{-2} \mathrm{M}$ did not affect attachment. Moreover, EDTA ( $0 \cdot 1$ to $\left.10 \mathrm{mM}\right)$ had no effect on attachment when added either before or after attachment took place. The decrease in attachment on increasing the ionic strength or the $\mathrm{pH}$ of the attachment mixture may indicate that electrostatic bonds participate in $M$. gallisepticum adherence to glass, as was suggested for the attachment of this mycoplasma to erythrocytes (Banai et al., 1978). However, changes in the ionic strength and $\mathrm{pH}$ can influence adherence not only by affecting the dissociation of charged groups on the cell and glass surface, but also by modifying membrane components involved in adherence. Thus, changes in ionic strength induced structural changes in a major protein of the erythrocyte membrane (Jenkins \& Tanner, 


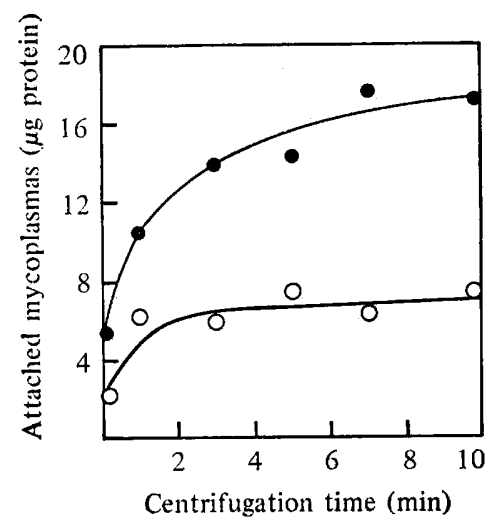

Fig. 2

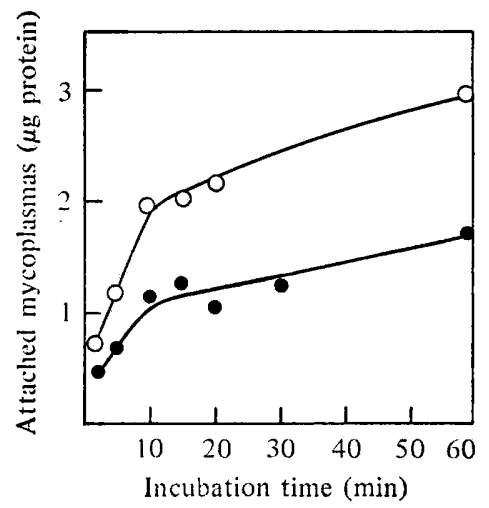

Fig. 3

Fig. 2. Effects of siliconization of test tubes and centrifugation on the attachment of $M$. gallisepticum to glass test tubes: $\bigcirc$, non-siliconized tubes; $O$, siliconized tubes. Each test tube contained $30 \mu \mathrm{g}$ protein. Centrifugation was done in a Sorvall GLC-2 centrifuge with a swing-out rotor at 1000 rev. min $^{-1}$. Siliconization of test tubes was done as described by Banai et al. (1978).

Fig. 3. Kinetics of the attachment of $M$. gallisepticum to glass at $0^{\circ} \mathrm{C}(O)$ and $37^{\circ} \mathrm{C}(\mathrm{O})$. Each test tube contained $22 \mu \mathrm{g}$ protein.

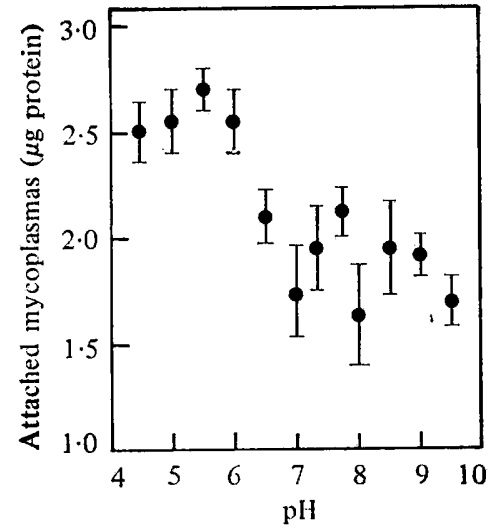

Fig. 4

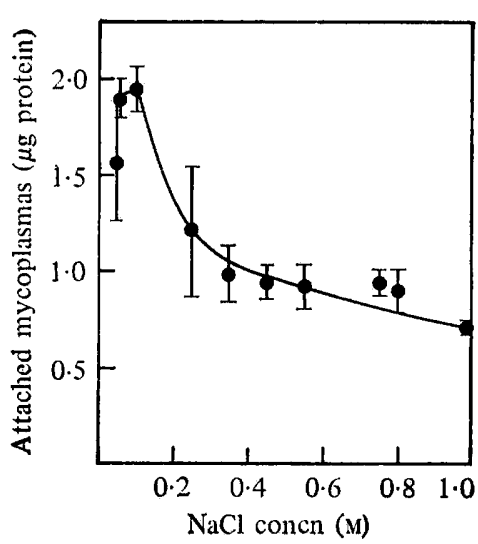

Fig. 5

Fig. 4. Effect of $\mathrm{pH}$ on the attachment of $M$. gallisepticum to glass. Each test tube contained $15 \mu \mathrm{g}$ protein.

Fig. 5. Effect of ionic strength on the attachment of $M$. gallisepticum to glass. Each test tube contained $13 \mu \mathrm{g}$ protein.

1977). The decreased attachment of $M$. gallisepticum at the lowest $\mathrm{NaCl}$ concentration tested (Fig. 5) may be due to swelling and possibly lysis of some cells in the hypotonic solution. The lack of any significant effect of divalent cations and EDTA on attachment is consistent with previous findings using $M$. pneumoniae (Gorski \& Bredt, 1977), indicating that salt bridges do not play a primary role in the attachment of these mycoplasmas to glass.

Glycophorin, the receptor site for $M$. gallisepticum on erythrocytes (Banai et al., 1978), inhibited attachment to glass when added to the attachment mixture, but did not detach mycoplasmas already attached to the glass. Asialoglycophorin, a derivative of glycophorin from which the sialic acid residues were removed by acid hydrolysis (Ben Shitrit \& Kahane, 
Table 1. Inhibition of $M$. gallisepticum attachment

to glass by glycophorin and bovine serum albumin

Protein concn in attachment mixture $\left(\mu \mathrm{g} \mathrm{ml}^{-1}\right)$

1
10
50
100
1000

\begin{tabular}{cc} 
Attached mycoplasmas* (\% of control) \\
\hline Glycophorin \\
$94 \cdot 3$ & $85 \cdot 5$ \\
$65 \cdot 5$ & $80 \cdot 1$ \\
$43 \cdot 3$ & $65 \cdot 1$ \\
$46 \cdot 4$ & $49 \cdot 4$ \\
Not tested & $20 \cdot 4$
\end{tabular}

* Mean values of three experiments with glycophorin and two with bovine serum albumin.

unpublished data), was as effective as glycophorin in blocking attachment, suggesting that inhibition by these proteins may be non-specific. Inhibition of attachment by bovine serum albumin supports this suggestion (Table 1). This observation is in accord with that of Purcell et al. (1971) who demonstrated that an increase in the serum content of the medium decreased the amount of mycoplasmas attaching to glass during growth. Bovine serum albumin at a concentration of $1 \mathrm{mg} \mathrm{ml}^{-1}$ also decreased attachment of $M$. pneumoniae to glass by about $80 \%$ (Bredt, unpublished data). It should be stressed that a priori the receptor sites for $M$. gallisepticum and $M$. pneumoniae must be different from those on the eukaryotic cell surface, since glass does not contain sialic acid, the specific ligand of the eukaryotic cell receptor for these mycoplasmas.

Membrane proteins exposed on the outer surface of $M$. pneumoniae have been implicated as the binding sites responsible for attachment to eukaryotic cells and to plastic ( $\mathrm{Hu}$ et al., 1977; Gorski \& Bredt, 1977). Treatment of $M$. gallisepticum with trypsin [50 $\mu \mathrm{g}$ (mg protein $)^{-1}$ ] for 30 min caused a 35 to $40 \%$ decrease in the ability of the organisms to attach to glass. Longer periods of treatment or higher trypsin concentrations caused lysis, as indicated by decreased turbidity of the mycoplasma suspension and increased specific radioactivity. Once the organisms were attached to the glass, neither trypsin (up to $100 \mu \mathrm{g}$ $\left.\mathrm{ml}^{-1}\right)$ nor pronase $\left(100 \mu \mathrm{g} \mathrm{ml}^{-1}\right)$ could detach them. We also tested whether trypsin could detach $M$. gallisepticum bound to the glass during growth. Judging by radioactivity measurements, about 15 to $25 \%$ of the growing organisms remained attached to the glass tube after washing. Treatment with trypsin $(50 \mu \mathrm{g}$ per tube for $30 \mathrm{~min})$ detached only up to $30 \%$ of the bound organisms. We suggest that in this case the enzyme cannot reach the proteinaceous binding sites once they are engaged, or that membrane components other than proteins take part in the attachment process. Our findings appear somewhat at variance with those of Somerson et al. (1967) and of Manchee \& Taylor-Robinson (1969) who showed that layers of $M$. pneumoniae and $M$. gallisepticum growth on glass and plastic could be detached by trypsin. In their experiments, however, they used high concentrations of crude trypsin (1 to $2.5 \%$ ) and relatively thick layers of mycoplasma, so it is possible that trypsin detached only those organisms which were not directly in contact with the glass. In conclusion, our experiments, showing that attachment capacity of $M$. gallisepticum to glass was only partially affected by extensive pretreatment of the cells with trypsin, strongly suggest that external cell components, in addition to membrane proteins, also participate in the attachment process.

This investigation was supported by grant $\mathrm{Br} 296 / 9$ from the Deutsche Forschungsgemeinschaft, Germany. 


\section{REFERENCES}

Banar, M., Kahane, I., Razin, S. \& BRedT, W. (1978). Adherence of Mycoplasma gallisepticum to human red blood cells. Infection and Immunity 21, 365-372.

GeSNer, B. \& Thomas, L. (1966). Sialic acid binding sites: role in hemagglutination by Mycoplasma gallisepticum. Science 151, 590-591.

GORSKI, F. \& BREDT, W. (1977). Studies on the adherence mechanism of Mycoplasma pneumoniae. FEMS Microbiology Letters 1, 265-268.

Hu, P. C., Collier, A. M. \& Baseman, J. B. (1977). Surface parasitism by Mycoplasma pneumoniae of respiratory epithelium. Journal of Experimental Medicine 145, 1328-1343.

JENkINS, R. E. \& TANNER, M. J. A. (1977). Ionicstrength-dependent changes in the structure of the major protein of the human erythrocyte membrane. Biochemical Journal 161, 131-138.

KaHANe, I. \& RAZIN, S. (1977). Cholesterolphosphatidylcholine dispersions as donors of cholesterol to mycoplasma membranes. Biochimica et biophysica acta 471, 32-38.

Lowry, O. H., Rosebrough, N. J., Farr, A. L. \& RANDALL, R. J. (1951). Protein measurement with the Folin phenol reagent. Journal of Biological Chemistry 193, 265-275.

MANCHEE, R. J. \& TAYLOR-Robinson, D. (1969). Utilization of neuraminic acid receptors by mycoplasmas. Journal of Bacteriology 98, 914-919.

Marchesi, V. T. \& ANDrews, E. P. (1971). The use of lithium diiodosalicylate (LIS) to isolate glycoproteins from cell membranes. Science 174, 12471248.

Purcell, R. H., Valdesuso, J. R., Cline, W. I., JAMES, W. D. \& Chanock, R. M. (1971). Cultivation of mycoplasmas on glass. Applied Microbiology 21, 288-294.

RAZIN, S. (1978). The mycoplasmas. Microbiological Reviews 42, 414-470.

Razin, S. \& RotTeM, S. (1976). Techniques for the manipulation of mycoplasma membranes. In Biochemical Analysis of Membranes, pp. 3-26. Edited by H. Maddy. London: Chapman and Hall.

Sobeslavisy, O., Prescott, B. \& Chanock, R. M. (1968). Adsorption of Mycoplasma pneumoniae to neuraminic acid receptors of various cells and possible role in virulence. Journal of Bacteriology 96, 695-706.

Somerson, N. L., JAmES, W.D., WALls, B. E. \& CHANOck, R. M. (1967). Growth of Mycoplasma pneumoniae on a glass surface. Annals of the New York Academy of Sciences 143, 384-389.

TAYlor-RoBinson, D. \& MANCHEe, R. J. (1967), Adherence of mycoplasma to glass and plastic. Journal of Bacteriology 94, 1781-1782.

Warren, J., Senterfit, L. B., SieIro, F. (1968). Inactivated culture vaccine against Mycoplasma gallisepticum infection in chickens. American Journal of Veterinary Research 29, 1659-1664. 